\title{
Effects of exogenous calcium on mesophyll cell ultrastructure, gas exchange, and photosystem II in tobacco (Nicotiana tabacum Linn.) under drought stress
}

\author{
W. HU* , S.B. TIAN ${ }^{* *}$, Q. DI ${ }^{* *+}$, S.H. DUAN ${ }^{* * *}$, and K. DAI ${ }^{* * * *}$ \\ College of Resources and Environment, Southwest University, Chongqing, China* \\ Vegetable and Flower Institute of Chongqing Academy of Agricultural Sciences, Chongqing, China** \\ Hunan Tobacco Science Institute, Changsha 410010, China ${ }^{* * *}$ \\ Biological Control of Tobacco Diseases and Insect Pests Engineering Research Center of China Tobacco, \\ Yuxi 653100, China ${ }^{* * * *}$
}

\begin{abstract}
The effects of calcium chloride solution $\left(10 \mathrm{mmol} \mathrm{L}^{-1}\right)$ on mesophyll cell ultrastructure, gas exchange, chlorophyll and carotenoid content, and PSII in tobacco leaf were studied by simulating water deficit conditions via treatment with $25 \%$ PEG-6000 for $24 \mathrm{~h}$. The results showed that under drought stress, the mesophyll cell structure and morphology were destroyed, photosynthesis and gas-exchange processes changed, photosynthetic pigment content decreased, and the electron transfer efficiency in PSII reduced. However, compared with the control treatment, under drought conditions, the addition of exogenous calcium could stabilize the structure and function of the chloroplasts, mitochondria, and endomembrane system in the mesophyll cells, maintain normal leaf net photosynthetic rate and gas exchange, alleviate the degree of photosynthetic pigment degradation, and increase the electron transfer energy in the leaves in PSII. As a means of ensuring normal photosynthesis under drought stress, we discovered that the application of exogenous calcium was more important for stabilization of the structure of the organelles, regulation of the osmotic balance, and increase of the photosynthetic pigment content, and proved to be less important for regulation of stomatal opening and closing.
\end{abstract}

Additional key words: abiotic stress; chlorophyll $a$ fluorescence; electron transport rate; foliar fertilizer.

\section{Introduction}

Flue-cured tobacco (Nicotiana tabacum Linn.) is one of the most highly valued crops worldwide. It is cultivated widely in the southwest of China in mountainous regions that are subjects to severe drought. In flue-cured tobacco production, drought stress affects tobacco growth at the rosette, vigorous growth, flowering, and maturing stages, while the worst impact on the yield and quality occurs at the vigorous growth stage (Wang et al. 2009). The value of tobacco depends largely on the yield and quality of its leaves, both of which are affected by photosynthesis. Drought does not only influence the cell structure and functioning of leaves, but also affects light energy capture, light absorption, electron transport, and heat dissipation, and thus photosynthesis. Increasing the photosynthetic efficiency of leaves under drought stress is significant for flue-cured tobacco production.

The decrease in photosynthetic rate observed during water deficit is not due to an insufficient supply of water, but rather due to limitations of stomatal or nonstomatal factors induced by drought stress (Wise et al. 1992). Calcium is not only a necessary nutrient for tobacco growth, but more importantly, it acts as a messenger for the coupling of extracellular signals and intracellular physiological responses, and plays an important role in the regulation of physiological processes, including the opening and closing of stomata (Ingram and Bartels 1996). In addition, calcium can stabilize the cell wall and a variety of organelle membrane structures, promotes NADP synthesis (White and Broadley 2003), is involved in plant hormone transport (Rickauer and Tanner 1986), and

Received 26 August 2017, accepted 7 February 2018, published as online-first 19 April 2018.

${ }^{+}$Corresponding author; e-mail: ayoula226@163.com

Abbreviations: Car - carotenoids; $C_{\mathrm{i}}$ - intercellular $\mathrm{CO}_{2}$ concentration; $\mathrm{Chl}$ - chlorophyll; $E$ - transpiration rate; $\mathrm{FM} \mathrm{-} \mathrm{fresh} \mathrm{mass;}$ $g_{\mathrm{s}}$ - stomatal conductance; NPQ - nonphotochemical quenching; ФPSII - effective quantum yield of PSII photochemistry; PEG polyethylene glycol; $P_{\mathrm{N}}-$ net photosynthetic rate; $\mathrm{q}_{\mathrm{p}}$ - photochemical quenching coefficient; $\psi_{\mathrm{w}}-$ water potential.

Acknowledgements: This study was supported by the Young Elite Scientists Sponsorship Program by the China Association for Science and Technology (2016QNRC001).

(C) The Author(s). This article is published with open access at link.springer.com 
maintains protective enzyme activities and antioxidant substance contents at a higher level while reducing the active oxygen content (Gong et al. 1997). The active oxygen molecules, such as $\mathrm{O}_{2}^{-}$and $\mathrm{H}_{2} \mathrm{O}_{2}$, could be rapidly generated by plant cells when exogenous $\mathrm{Ca}^{2+}$ is present. These molecules produce signals that cause a serie of protective physiological responses so as to reduce salt damage, oxidative stress, and drought stress (Xu and Heath 1998). Though numerous studies have focused on the

\section{Materials and methods}

Plant material and drought treatment: Nicotiana tabacum L. cv. QX1, developed by the Bijie Tobacco Company of Guizhou Province, was used in this study. Tobacco seeds were surface-disinfected in $0.1 \% \mathrm{HgCl}_{2}$ for $10 \mathrm{~min}$ and soaked in sterile water for $15 \mathrm{~min}$, after which they were rinsed 3 times. The seeds were sowed into polyurethane foam soaked in tap water in a plastic pot and germinated for $3 \mathrm{~d}$. Seven days after seeding, the polyurethane foam was planted into an expanded polystyrene board over a polypropylene container (inner volume of $1.6 \mathrm{~L}$ ). The seedlings were grown in a nutrient solution with the following components: $1.6 \mathrm{mmol}\left(\mathrm{NO}_{3}{ }^{-}\right) \mathrm{L}^{-1}, 0.4$ mmol(phosphate) $\mathrm{L}^{-1}, 4 \mathrm{mmol}(\mathrm{K}) \mathrm{L}^{-1}, 4 \mathrm{mmol}(\mathrm{Ca}) \mathrm{L}^{-1}$, $2 \mathrm{mmol}(\mathrm{Mg}) \mathrm{L}^{-1}, 0.01 \mathrm{mmol}(\mathrm{Fe}) \mathrm{L}^{-1}$, and $0.01 \mathrm{mmol}($ trace elements) $\mathrm{L}^{-1}$ (including $\mathrm{Mn}, \mathrm{Zn}, \mathrm{Na}, \mathrm{Cu}$, and $\mathrm{Co}$ ). Deionized water was added to maintain the volume of the nutrient solution at $1.5 \mathrm{~L}$. Each container contained two tobacco seedlings and there were three replicates in each treatment. The seeds were grown at $22.5^{\circ} \mathrm{C}$ under a $16-\mathrm{h}$ light/8-h dark cycle and fluorescent lamps with an average PPFD of $300 \mu \mathrm{mol} \mathrm{m} \mathrm{m}^{-2} \mathrm{~s}^{-1}$ were used in a greenhouse. Seven-week-old tobacco plants were subjected to drought stress by adding 25\% polyethylene glycol (PEG)-6000 to the nutrient solution for $24 \mathrm{~h}$.

Experimental design: Tobacco leaves under the same growth conditions were selected for experiments. There were three treatments, including (1) CK: no addition of 25\% PEG-6000; (2) +Ca: 25\% PEG-6000 was added with exogenous calcium; and (3) -Ca: 25\% PEG-6000 was added without exogenous calcium application. Each treatment had 6 repetitions. The exogenous calcium as $10 \mathrm{mmol}\left(\mathrm{CaCl}_{2}\right) \mathrm{L}^{-1}$ solution was sprayed uniformly on the abaxial and adaxial surfaces of the tobacco leaves. In order to ensure that the $\mathrm{CaCl}_{2}$ was fully absorbed, the spraying was repeated once with the same dosage until the $\mathrm{CaCl}_{2}$ solution on the leaf surface evaporated. The $-\mathrm{Ca}$-treated plants were sprayed with tap water similarly as a control.

Leaf water potential was measured as described in the literature (Cho and Hong 2006). Leaves in the same position and of the same size from both treatments were sampled around midday. A dew-point potential meter (model WP4, Decagon Instrument, USA) was used for leaf water potential measurements. physiological roles of calcium in plant drought tolerance, comparative analyses on the effects of drought stress on the cell structure and photosynthetic physiology in tobacco leaves are scarce. In this paper, we investigated the effects of exogenous calcium on leaf mesophyll cell ultrastructure, gas exchange, and PSII in tobacco under drought stress. This study may enhance our understanding of the role of calcium in improving drought resistance in tobacco.

Transmission electron microscope (TEM) sample preparation and observation: Square samples $(0.5 \mathrm{~cm} \times$ $0.5 \mathrm{~cm})$ were collected from near the center vein of each leaf. After soaking with $2.5 \%$ glutaraldehyde for $4 \mathrm{~h}$, the leaf cells were fixed with osmic acid at $4^{\circ} \mathrm{C}$ for $4 \mathrm{~h}$ and then dehydrated with ethanol. Once embedded in Spurr's resin at $70^{\circ} \mathrm{C}$ for $8 \mathrm{~h}$, thin sections were cut from the leaf samples with an $L K B-V$ ultramicrotome ( $L K B$, Sweden) and placed upon 250-mesh grids (Xu et al. 2008).

Leaf gas-exchange parameters: Net photosynthetic rate $\left(P_{\mathrm{N}}\right)$, stomatal conductance $\left(g_{\mathrm{s}}\right)$, intercellular $\mathrm{CO}_{2}$ concentration $\left(C_{\mathrm{i}}\right)$, and transpiration rate $(E)$ were determined during 8:30-10:30 h on fully expanded leaves using a portable open-flow gas-exchange system LI-6400 ( $L I$ COR Biosciences, Lincoln, USA) (Huo et al. 2016). These parameters were measured under the following conditions: LED light source with PPFD of $800 \mu \mathrm{mol} \mathrm{m} \mathrm{m}^{-2}$; flow rate of $500 \mu \mathrm{mol} \mathrm{s}{ }^{-1}$; leaf temperature of $30 \pm 2^{\circ} \mathrm{C}$; and relative humidity of $60 \pm 1 \%$.

Chlorophyll (Chl) and carotenoid (Car) contents: The Chl contents were assessed using a spectrophotometer (UV-1100, Mapada, China) at 663 and $645 \mathrm{~nm}$ after soaking the leaves in $15 \mathrm{~mL}$ of $95 \%$ ethanol for $48 \mathrm{~h}$ in darkness. Car were extracted with acetone and spectrophotometric determinations were performed at $440 \mathrm{~nm}$. The calculations used the methods as in Liu and Shi (2010) and the contents were expressed in $\left[\mathrm{mg} \mathrm{g}^{-1}(\mathrm{FM})\right]$.

$$
\begin{aligned}
& \text { Chl } a\left[\mathrm{mg} \mathrm{L}^{-1}\right]=12.72 \mathrm{~A}_{663}-2.59 \mathrm{~A}_{645} \\
& \text { Chl } b\left[\mathrm{mg} \mathrm{L}^{-1}\right]=22.88 \mathrm{~A}_{645}-4.67 \mathrm{~A}_{663} \\
& \text { Chl }(a+b)=\mathrm{Chl} a+\mathrm{Chl} b=8.05 \mathrm{~A}_{663}-20.29 \mathrm{~A}_{645} \\
& \text { Car }\left[\mathrm{mg} \mathrm{L}^{-1}\right]=4.7 \mathrm{~A}_{440}-0.27 \mathrm{Chl}(a+b)
\end{aligned}
$$

Calculation of $\mathrm{Chl}$ and Car contents in leaves: $\mathrm{X}=0.25 \mathrm{C} / \mathrm{W}$

where $\mathrm{X}-\mathrm{Chl}$ or Car content; $\mathrm{C}$ - concentration of $\mathrm{Chl}$ or Car in the extract; $\mathrm{W}-$ fresh mass (FM) of the sample.

Chl $\boldsymbol{a}$ fluorescence was measured using a 6400-40 leaf chamber fluorometer (LI-COR Biosciences, Lincoln, USA) on the same leaves used for the gas-exchange measurements. The blades were kept in the dark overnight before recording the fluorescence. The minimal fluorescence yield of the dark-adapted state $\left(\mathrm{F}_{0}\right)$ was obtained 
under a weak pulse of modulating light over a 0.8 -s period when the fluorescence level was stable. The maximal fluorescence yield of the dark-adapted state $\left(F_{m}\right)$ was induced by a saturating pulse of light $[8,000 \mu \mathrm{mol}$ (photon) $\mathrm{m}^{-2} \mathrm{~s}^{-1}$ ] applied over $0.8 \mathrm{~s}$. The maximal quantum yield of PSII photochemistry was determined as $F_{v} / F_{m}$, where $F_{v}$ is the difference between $\mathrm{F}_{0}$ and $\mathrm{F}_{\mathrm{m}}$. An actinic light source [600 $\mu$ mol(photon) $\mathrm{m}^{-2} \mathrm{~s}^{-1}$ ] was then applied to achieve steady-state photosynthesis and to obtain $\mathrm{F}_{\mathrm{s}}$, after which the second saturation pulse was applied for $0.8 \mathrm{~s}$ to obtain $\mathrm{F}_{\mathrm{m}}$ ' (maximal fluorescence yield of the light-adapted state). The fluorescence parameter $\mathrm{F}_{0}$ ' (minimal fluorescence yield of the light-adapted state) was obtained by far infrared light radiation for $3 \mathrm{~s}$. The parameters, were calculated as follows:

\section{Results}

Water conditions: Little change was observed in the control treatment after $24 \mathrm{~h}$. However, the addition of $25 \%$ PEG-6000 resulted in the leaves displaying obvious signals of water stress (Table 1). The water potential of the $+\mathrm{Ca}$ treatments was $-0.53 \mathrm{MPa}$ and $-\mathrm{Ca}$ treatment was $-1.14 \mathrm{MPa}$, which were significantly lower than that of the control. While the water potential of the $+\mathrm{Ca}$ treatment was significantly higher than the -Ca treatment, suggesting that exogenous calcium was able to alleviate drought stress to some extent.

Cell structure: The leaf mesophyll cell ultrastructure of CK was normal (Fig. 1). The nucleus was biased towards one side of the distribution; the chloroplasts in the cells were situated close to the cell wall; the volume of the starch granules in the chloroplasts was relatively small; and the chloroplast had a complete outer envelope and a clear boundary, the main form of which was a long oval. The thylakoid system was well developed; the osmium particle content was relatively large and the electron density was high. There was a small amount of high electron density osmiophilic material distributed in the central large vacuole and vacuolar membrane. The mitochondria were abundant in the cytoplasm and the nucleus appeared normal.

Compared with the control, the ultrastructure of the

$$
\begin{array}{ll}
\mathrm{F}_{\mathrm{v}} / \mathrm{F}_{\mathrm{m}}=\left(\mathrm{F}_{\mathrm{m}}-\mathrm{F}_{0}\right) / \mathrm{F}_{\mathrm{m}}, & \mathrm{q}_{\mathrm{p}}=\left(\mathrm{F}_{\mathrm{m}}{ }^{\prime}-\mathrm{F}_{\mathrm{s}}\right) /\left(\mathrm{F}_{\mathrm{m}}{ }^{\prime}-\mathrm{F}_{0}{ }^{\prime}\right) \\
\Phi_{\mathrm{PSII}}=\left(\mathrm{F}_{\mathrm{m}}{ }^{\prime}-\mathrm{F}_{\mathrm{s}}\right) / \mathrm{F}_{\mathrm{m}}, & \mathrm{NPQ}=\left(\mathrm{F}_{\mathrm{m}}-\mathrm{F}_{\mathrm{m}}{ }^{\prime}\right) / \mathrm{F}_{\mathrm{m}}{ }^{\prime}
\end{array}
$$

The NPQ was calculated according to the SternVolmer equation (Bilger and Björkman 1991).

Statistical analysis: The data in the tables and figures are expressed as the means of all replicates $\pm \mathrm{SD}$. Data were statistically analyzed by analysis of variance (ANOVA) using SAS version 9.3 (Statistical Analysis System Institute Inc., Cary, NC, USA). Statistical significance was assessed using the least significant difference (LSD) test $(P<0.05)$. Pearson's linear correlation analysis was performed on the gas-exchange indexes. leaf mesophyll cells treated with exogenous $+\mathrm{Ca}$ exhibited no obvious change. The nucleus was biased towards one side of the distribution; most chloroplasts in the cells were situated close to the cell wall and the main form was still a long oval; the chloroplast membrane structure was relatively complete and swelling appeared in some of the chloroplasts. The starch granules were smaller. The content and volume of the osmium particles changed little and the electronic density was slightly higher than the control. There was also a small amount of high electron density osmiophilic substance distributed in the central large vacuole and on the vacuolar membrane. The mitochondria in the cytoplasm remained abundant and most were normal, and the nucleus was essentially normal.

The ultrastructure of the mesophyll cells in the tobacco leaves without exogenous $\mathrm{Ca}^{2+}$ treatment exhibited typical characteristics of plant leaf cells under drought stress. Specifically, the nucleus became blurred; the chloroplasts in the cells were swollen and had become separated from the cell wall; the starch granules in the chloroplast were partially degraded; the chloroplast membrane was broken; the main form of the chloroplast was round; the thylakoid lamellae were severely dilated and distorted; the osmium particle content had increased; the electron density was still high, and the majority of the mitochondria disintegrated.

Table 1. Effects of drought stress on the water status of flue-cured tobacco leaves. Different letters within the same row indicate significant difference $(P<0.05)$. CK - no addition of 25\% PEG-6000; $+\mathrm{Ca}-25 \%$ PEG-6000 was added with applying exogenous calcium; $-\mathrm{Ca}-25 \%$ PEG-6000 was added without exogenous calcium application; $\psi_{\mathrm{w}}-$ water potential.

\begin{tabular}{lllll}
\hline & CK $(24 \mathrm{~h}$ before $)$ & $\mathrm{CK}$ & $+\mathrm{Ca}$ & $-\mathrm{Ca}$ \\
\hline$\psi_{\mathrm{w}}[\mathrm{MPa}]$ & $-0.12 \pm 0.01^{\mathrm{a}}$ & $-0.13 \pm 0.01^{\mathrm{a}}$ & $-0.53 \pm 0.18^{\mathrm{b}}$ & $-1.14 \pm 0.21^{\mathrm{c}}$ \\
Degrees of freedom & 5 & 5 & 5 & 5 \\
\hline
\end{tabular}




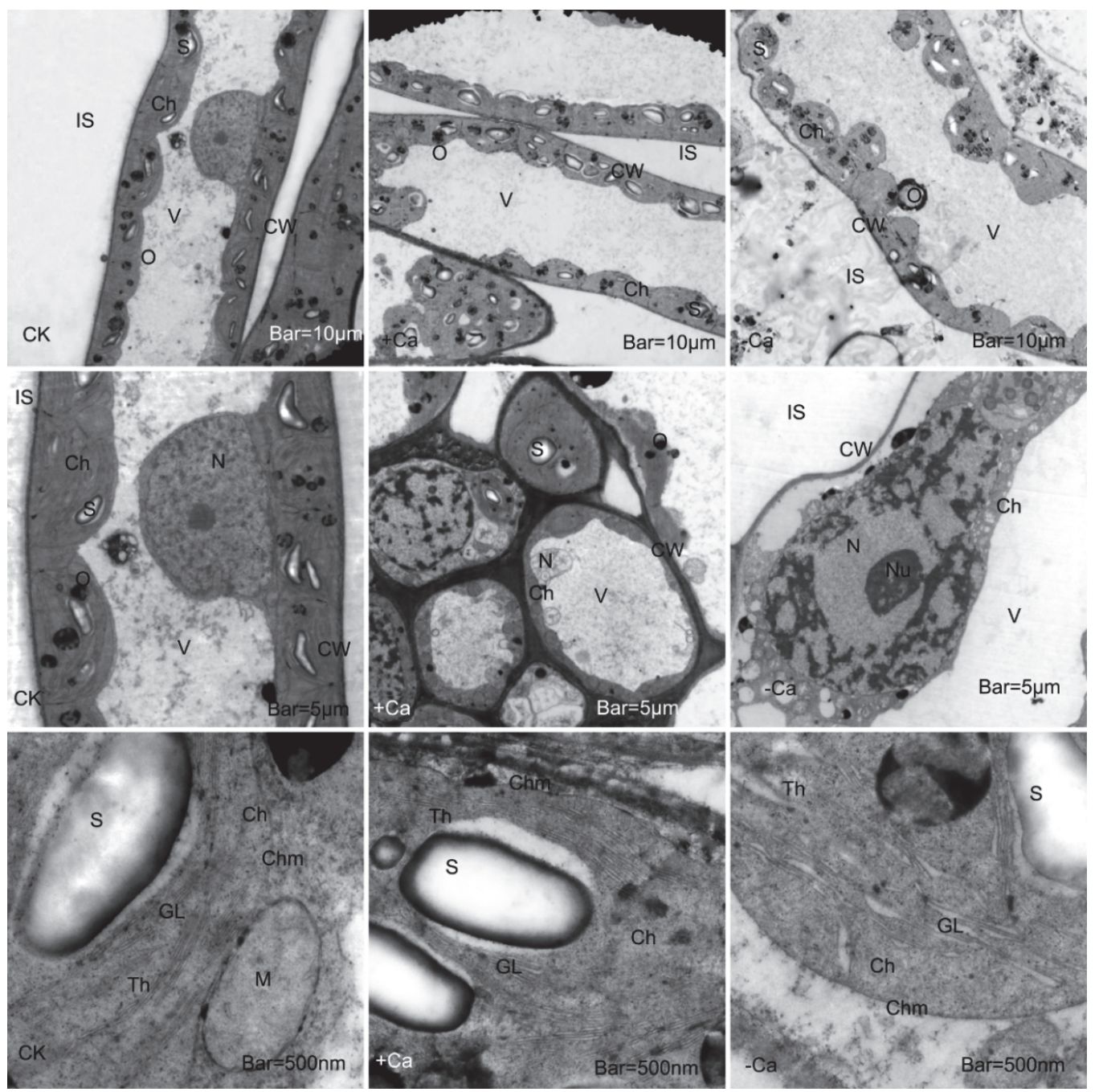

Fig. 1. Effect of exogenous calcium on the cell structure of tobacco leaves under drought stress. The three treatments are indicated from the left to the right in the figure, while the same treatments at different magnification are shown from the top to the bottom. CK - control treatment; $+\mathrm{Ca}$ - treatment with exogenous $\mathrm{Ca}^{2+} ;-\mathrm{Ca}$ - treatment without exogenous $\mathrm{Ca}^{2+}$. IS - cell gap; $\mathrm{V}-$ vacuole; $\mathrm{Ch}-$ chloroplast; $\mathrm{Chm}$ - chloroplast membrane; $\mathrm{S}$ - starch granules; $\mathrm{O}$ - osmium granules; $\mathrm{CW}$ - cell wall; $\mathrm{N}$ - nucleus; $\mathrm{Nu}$ - nucleolus; $\mathrm{M}$ - mitochondria; GL - basal lamellae; Th - matrix thylakoid.

Leaf gas exchange: Drought stress influences photosynthesis; changes in gas exchange processes is one of specific manifestations of this effect. The results showed that the $P_{\mathrm{N}}$ of the control was $10.89 \mu \mathrm{mol} \mathrm{m} \mathrm{m}^{-2} \mathrm{~s}^{-1}, C_{\mathrm{i}}$ was $175.22 \mu \mathrm{mol}\left(\mathrm{CO}_{2}\right) \mathrm{mol}^{-1}, E$ was $3.4 \mathrm{mmol}\left(\mathrm{H}_{2} \mathrm{O}\right) \mathrm{m}^{-2} \mathrm{~s}^{-1}$, and $g_{\mathrm{s}}$ was $0.128 \mathrm{mmol}\left(\mathrm{H}_{2} \mathrm{O}\right) \mathrm{m}^{-2} \mathrm{~s}^{-1}$. Compared with the control, the $P_{\mathrm{N}}$ values of the treatment with and without exogenous calcium were reduced by 34.7 and $50.1 \%$; $E$ values decreased by 23.5 and $38.2 \% ; g_{\text {s }}$ decreased by 65.6 and $92.9 \%$; and $C_{\mathrm{i}}$ increased by 46.6 and $76.1 \%$. The results of the variance analysis (Fig. 2) showed that there were significant differences between the treatment $-\mathrm{Ca}$ and the control with regards to all indexes. Treatment $+\mathrm{Ca}$ did not differ significantly from the control in all indexes, with the exception of $g_{\mathrm{s}}$.

In order to clarify the role of calcium in reducing the effects of drought stress on photosynthesis in tobacco leaves, Pearson's linear correlation analysis was performed on the $P_{\mathrm{N}}, C_{\mathrm{i}}, E$, and $g_{\mathrm{s}}$ indexes. The results of the analysis are presented in Table 2. $P_{\mathrm{N}}$ was significantly negatively correlated with $C_{\mathrm{i}}$ and significantly positively correlated with $E$. There was a significant negative correlation between $C_{\mathrm{i}}$ and $E . g_{\mathrm{s}}$ was significantly negatively correlated with $C_{\mathrm{i}}$ and significantly positively correlated with $E$ and $P_{\mathrm{N}}$. It can be deduced from the increase in the $C_{\mathrm{i}}$ value of the mesophyll cells after drought stress that the decrease in $P_{\mathrm{N}}$ value explains the decrease in $g_{\mathrm{s}}$. If the $P_{\mathrm{N}}$ value is reduced as a result of the decrease in the $g_{\mathrm{s}}$ value, then the value of $C_{\mathrm{i}}$ should also be reduced. This indicates that the reduction in photosynthetic efficiency caused by drought stress in this experiment was dominated by nonstomatal factors, and the stomatal factor was secondary. 


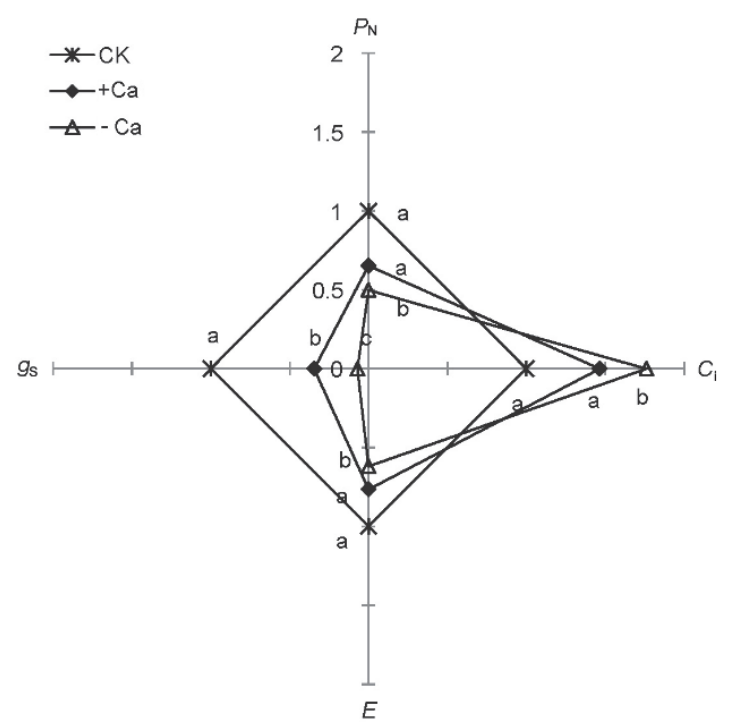

Fig. 2. Effects of exogenous calcium on gas exchange in tobacco leaves under drought stress. $P_{\mathrm{N}}-$ net photosynthetic rate $[\mu \mathrm{mol}$ $\left.\mathrm{m}^{-2} \mathrm{~s}^{-1}\right] ; C_{\mathrm{i}}$ - intercellular $\mathrm{CO}_{2}$ concentration $\left[\mu \mathrm{mol}\left(\mathrm{CO}_{2}\right) \mathrm{mol}^{-1}\right]$; $E$ - transpiration rate $\left[\mathrm{mmol}\left(\mathrm{H}_{2} \mathrm{O}\right) \mathrm{m}^{-2} \mathrm{~s}^{-1}\right] ; g_{\mathrm{s}}-$ stomatal conductance $\left.\left[\mathrm{mmol}\left(\mathrm{H}_{2} \mathrm{O}\right) \mathrm{m}^{-2} \mathrm{~s}^{-1}\right)\right]$; different letters indicate significant differences between each treatment at $P \leq 0.05$, according to the LSD test. In order to facilitate comparison, the values of each parameter in control (CK) were converted to 1 and the parameter values in the other treatments were proportionately converted according to $\mathrm{CK}$.

Table 2. Pearson's linear correlation coefficient between leaf gas exchange parameters. ${ }^{*}$ significant at $P<0.05,{ }^{* *}$ significant at $P<0.01$. $P_{\mathrm{N}}-$ net photosynthetic rate; $C_{\mathrm{i}}-$ intercellular $\mathrm{CO}_{2}$ concentration; $E$ - transpiration rate; $g_{\mathrm{s}}-$ stomatal conductance.

\begin{tabular}{lllll}
\hline & $P_{\mathrm{N}}$ & $C_{\mathrm{i}}$ & $E$ & $g_{\mathrm{s}}$ \\
\hline$P_{\mathrm{N}}$ & 1 & & & \\
$C_{\mathrm{i}}$ & $-0.97^{*}$ & 1 & & \\
$E$ & $0.96^{*}$ & $-0.99^{* *}$ & 1 & \\
$g_{\mathrm{s}}$ & $0.92^{*}$ & $-0.94^{*}$ & $0.93^{*}$ & 1 \\
\hline
\end{tabular}

\section{Discussion}

Complete configuration and structure in mesophyll cells is required for ensuring normal leaf photosynthesis in tobacco. However, the cell structure and chloroplast morphology change under water deficit. It was previously observed that the internal membrane system, including the grana and stroma lamellae of the chloroplast, was almost devastated and the starch granules almost totally disappeared under conditions of water deficit in the mesophyll cells of a perennial grass (Xu et al. 2009). At the same time, drought-induced lipid peroxidation results in a massive reorganization of the chloroplast ultrastructure, including the swelling of the chloroplast and a change in chloroplast morphology from an ellipse to a circle (Anjum et al. 2011, Verslues et al. 2006). Calcium can stabilize the
Table 3. Effects of exogenous calcium on $\mathrm{Chl}$ and Car contents in leaves under drought stress. Different letters within the same column indicate significant difference $(P<0.05)$. $\mathrm{C}-$ no addition of $25 \%$ PEG-6000; $+\mathrm{Ca}-25 \%$ PEG-6000 was added with applying exogenous calcium; $-\mathrm{Ca}-25 \%$ PEG-6000 was added without exogenous calcium application; Chl - chlorophyll; Car - carotenoids.

\begin{tabular}{lll}
\hline Treatment & $\mathrm{Chl}\left[\mathrm{mg} \mathrm{g}^{-1}(\mathrm{FM})\right]$ & $\mathrm{Car}\left[\mathrm{mg} \mathrm{g}^{-1}(\mathrm{FM})\right]$ \\
\hline $\mathrm{CK}$ & $1.74 \pm 0.11^{\mathrm{a}}$ & $0.29 \pm 0.01^{\mathrm{a}}$ \\
$+\mathrm{Ca}$ & $1.65 \pm 0.08^{\mathrm{a}}$ & $0.24 \pm 0.01^{\mathrm{a}}$ \\
$-\mathrm{Ca}$ & $1.35 \pm 0.07^{\mathrm{b}}$ & $0.18 \pm 0.01^{\mathrm{b}}$ \\
\hline
\end{tabular}

Chl and Car: Drought stress can cause the degradation of photosynthetic pigments, including $\mathrm{Chl}$ and $\mathrm{Car}$. It can be seen from Table 3 that the $\mathrm{Chl}$ and Car contents in the leaves under drought stress decreased compared with the control. Chl and Car contents between the control and $+\mathrm{Ca}$ treatment did not differ significantly. However, Chl and Car contents in the -Ca treatment were significantly lower than in $\mathrm{CK}$ and $+\mathrm{Ca}$. This indicates that the $+\mathrm{Ca}$ treatment could effectively alleviate the degree of photosynthetic pigment degradation caused by drought stress within the scope of this experiment.

PSII: Drought stress reduces the light and efficiency of flue-cured tobacco not only because it causes damage to the photosynthetic apparatus, but also affects the transfer of electrons in PSII. It can be seen from Fig. 3 that $F_{0}$ and NPQ of the $-\mathrm{Ca}$ treatment significantly increased under drought stress, while $F_{\mathrm{v}} / \mathrm{F}_{\mathrm{m}}, \mathrm{q}_{\mathrm{p}}$, and $\Phi_{\text {PSII }}$ significantly decreased compared with the control. At the same time, the parameters of the $+\mathrm{Ca}$ treatment were not significantly different from the control. This indicated that treatment with exogenous calcium could increase activity in the PS II reaction center in the leaves.

membrane structure and maintain cell integrity by tied the phosphate, organophosphate, and the carboxyl groups of the protein together on the membrane surface. In addition, $\mathrm{Ca}^{2+}$, which is present in the protoplast membrane, can regulate the permeability of the membrane and affect the physiological and biochemical processes associated with it (Zhu et al. 2013). In our study, the ultrastructure of the mesophyll cells in the $+\mathrm{Ca}$ treatment did not change much under drought stress in comparison with the control treatment. The chloroplasts and membrane structure were normal, the capsule system was complete, and the mitochondria remained abundant. This signifies that the photosynthetic process was not severely impacted under drought stress. 


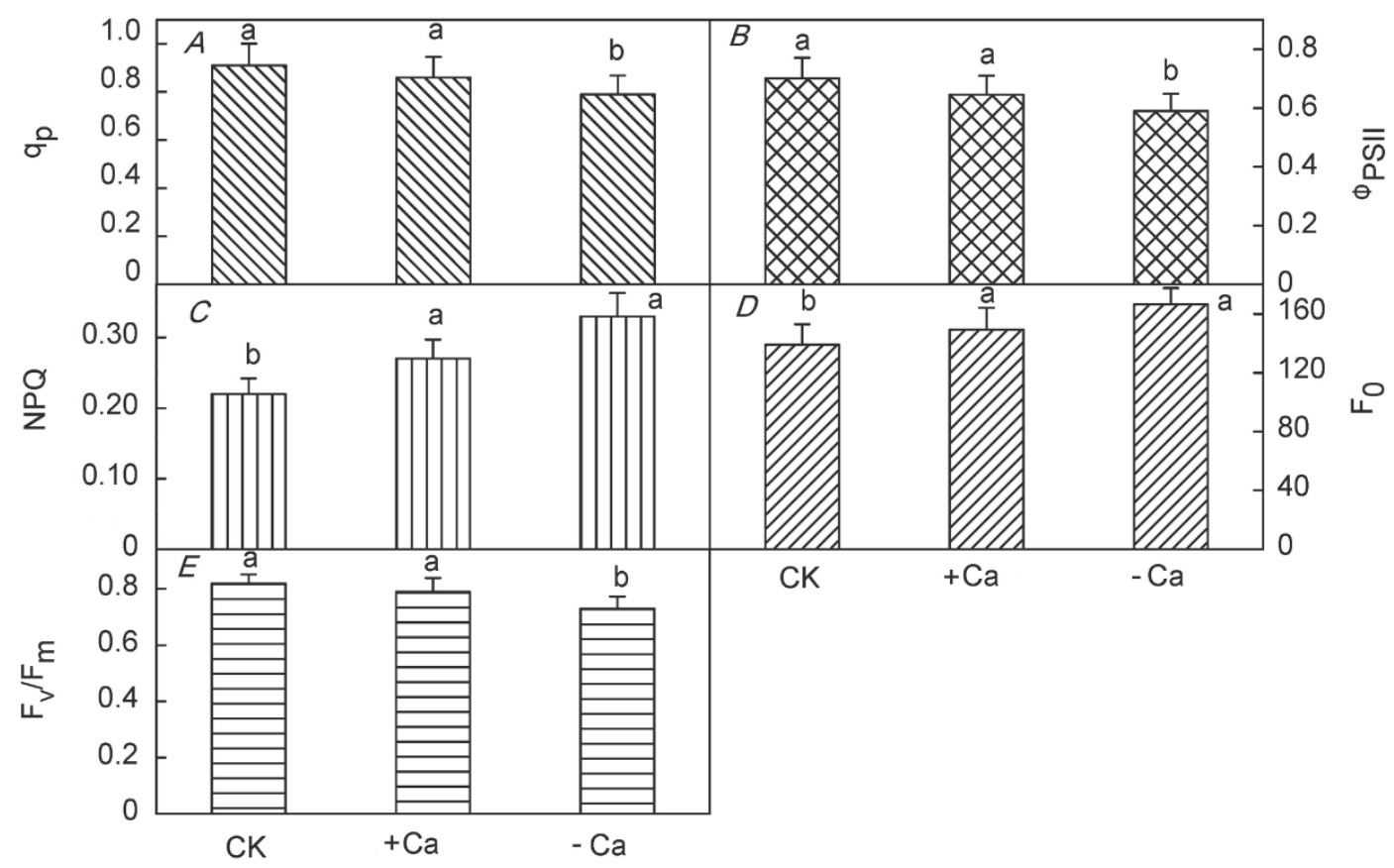

Fig. 3. Effects of exogenous calcium on minimal fluorescence yield of the dark-adapted state $\left(\mathrm{F}_{0}\right)$, maximal quantum yield of PSII photochemistry $\left(\mathrm{F}_{\mathrm{v}} / \mathrm{F}_{\mathrm{m}}\right)$, photochemical quenching coefficient $\left(\mathrm{q}_{\mathrm{p}}\right)$, effective quantum yield of PSII photochemistry (ФPSII), and nonphotochemical quenching (NPQ) in tobacco leaves under drought stress. Means followed by different letters in the same curve are significantly different at $P \leq 0.05$ according to the LSD test.

According to Farquhar and Sharkey (1982), a reduction in $P_{\mathrm{N}}$ can only contribute to a decrease in $g_{\mathrm{s}}$ when $C_{\mathrm{i}}$ is reduced. In contrast, when the $P_{\mathrm{N}}$ decreases along with an increase in $C_{\mathrm{i}}$, photosynthesis is mainly limited by nonstomatal factors. Analyzing the role of exogenous calcium on the resistance of tobacco to drought stress should elucidate the cause of the decline in $P_{\mathrm{N}}$. In our study, reductions in photosynthetic efficiency caused by drought stress were mainly due to nonstomatal factors. The variance analysis of the leaf gas-exchange parameters under drought stress indicated that the leaves positively reduced gas interactions to retain moisture, resulting in lower photosynthetic efficiency. It was reported that calcium treatment could improve Rubisco activity under abiotic stress, which was associated with the higher photosynthetic rate in leaves (Tan et al. 2011). Compared with the -Ca treatment, treatment of the mesophyll tissue with exogenous calcium had little impact on gas exchange, but $P_{\mathrm{N}}$ slightly decreased. The Pearson's test results (Table 2) indicated that although calcium could control the opening and closing of the plant leaf stomata, when the decrease in $P_{\mathrm{N}}$ was dominated by nonstomatal factors, the regulation by calcium was not the primary factor maintaining photosynthetic efficiency under drought stress (Chen et al. 2016, Tan and Buttery 1982). In other words, the role of exogenous calcium in improving the photosynthetic efficiency of tobacco leaves under severe drought stress was not related to stomatal adjustment.

Car in leaves include beta-carotene and lutein. Betacarotene can quench the ${ }^{1} \mathrm{O}_{2}$ produced by the ${ }^{3} \mathrm{P} 680$ that reacts with $\mathrm{O}_{2}$, while not quenching the ${ }^{3} \mathrm{P} 680$ itself. In addition to dissipation of excess light energy from chloroplast by interacting with the $\mathrm{Chl}$ of the singlet excited state, lutein also plays a role in lipid membrane peroxidation (Reif et al. 2013, Elgersma et al. 2015). Water deficit can reduce the photosynthetic pigment content in chloroplasts, resulting in a decline in leaf photosynthesis (Zhou and Lin 1995). In this experiment, the reaction center of PSII exhibited light-induced injury because the photosynthetic pigment content decreased as a result of drought stress (Table 3). It has been reported that $\mathrm{Ca}$-treated plant leaves have a higher $\mathrm{Chl}$ content. At the same time, Chl degradation is the first sign of $\mathrm{Ca}$ deficiency in plants. This indicated that $\mathrm{Ca}$ plays an important role in the regulation of leaf senescence (Dolatabadian et al. 2013). After a pretreatment by 5 and $10 \mathrm{mM} \mathrm{CaCl}_{2}$, plants exhibited noticeably an increased Chl content in the drought-stressed plants. It seems that the applied $\mathrm{CaCl}_{2}$ might prevent damage from cellular dehydration by balancing the osmotic strength of the cytoplasm (Xu et al. 2013). On the other hand, calcium contributes to the synthesis of betaine dehydrogenase, which is the key enzyme for the synthesis of betaine. The addition of exogenous calcium allows betaine to accumulate in the chloroplasts, which could alleviate the decrease in photosynthetic pigment contents under drought stress and maintain normal photosynthetic system operation.

The values of $\mathrm{F}_{\mathrm{v}} / \mathrm{F}_{\mathrm{m}}$ decreased under drought stress, indicating that photoinhibition occurred in the tobacco 
leaves. The increase in $\mathrm{F}_{0}$ values demonstrated that the PSII reaction center appeared to be either irreversibly damaged or reversibly inactivated. $\mathrm{q}_{\mathrm{p}}$ represents the proportion of open reaction centers in the total PSII reaction center, which determines the capture rate of excitation energy in PSII. The NPQ value reflects the state of heat dissipation in the reaction center ( $\mathrm{Lu}$ and Vonshak 2002). According to the NPQ and $\mathrm{q}_{\mathrm{p}}$ values (Fig. 2), it is evident that the proportion of the open reaction centers under drought stress was reduced, and the $\mathrm{Q}_{\mathrm{A}^{-}}$reduction level and the degree of heat dissipation increased. These data indicate that the increase in the $\mathrm{F}_{0}$ value of the PSII system is due to irreversible damage rather than reversible inactivation ( $\mathrm{Hu}$ et al. 2007). The regulatory function of $\mathrm{Ca}^{2+}$ includes processes such as the Calvin-BensonBassham cycle and providing $\mathrm{NADP}^{+}$as the terminal electron acceptor for photosynthesis. But most remarkable is the key role of $\mathrm{Ca}^{2+}$ in cyclic and electron flow (Hochmal et al. 2015). In our study, +Ca treatment increased the electron transfer energy in tobacco leaves, relatively increased the proportion of open reaction centers and electron transfer rates in PSII, and relieved photoinhibition under drought stress. Two explanations might account for the effects of calcium on PSII. First, as mentioned earlier, calcium can maintain photosynthetic pigment functioning and avoid its detachment or disintegration so as to ensure photosynthetic electron transport. Second, calcium is able to maintain membrane function and enhance cell membrane structure stability by forming calcium salts with phospholipid molecules in the thylakoid membrane (Betterle et al. 2015, 2017).

Conclusions: After treatment with 25\% PEG-6000 for $24 \mathrm{~h}$, the tobacco leaves showed obvious signs of water stress. In our study, the addition of exogenous calcium under drought conditions was found to stabilize the structure and function of the chloroplast, mitochondria, and endomembrane system in the mesophyll cells, maintain normal leaf net photosynthetic rate and gas exchange, alleviate the degree of photosynthetic pigment degradation, and ensure the regular operation of PSII. In addition to this, we discovered that exogenous calcium is more important for stabilizing the structure of the organelles, regulating osmotic balance, and increasing the photosynthetic pigment content, rather than for regulating leaf stomatal opening and closing.

Open Access This article is distributed under the terms of the Creative Commons Attribution License which permits any use, distribution, and reproduction in any medium, provided the original author(s) and the source are credited.

\section{References}

Anjum S.A., Wang L.C., Farooq M. et al.: Brassinolide application improves the drought tolerance in maize through modulation of enzymatic antioxidants and leaf gas exchange. J. Agron. Crop Sci. 197: 177-185, 2011.

Betterle N., Ballottari M., Baginsky S. et al.: High lightdependent phosphorylation of photosystem II inner antenna CP29 in Monocots is STN7 independent and enhances nonphotochemical quenching. - Plant Physiol. 167: 457-471, 2015.

Betterle N., Poudyal R.S., Rosa A. et al.: The STN8 kinase-PBCP phosphatase system is responsible for high-light-induced reversible phosphorylation of the PSII inner antenna subunit CP29 in rice. - Plant J. 89: 681-691, 2017.

Bilger W., Björkman O.: Temperature-dependence of violaxanthin deepoxidation and nonphotochemical fluorescence quenching in intact leaves of Gossypium hirsutum L and Malva parviflora L. - Planta 184: 226-234, 1991.

Chen D.Q., Wang S.W., Cao B.B. et al.: Genotypic variation in growth and physiological response to drought stress and rewatering reveals the critical role of recovery in drought adaptation in maize seedlings. - Front Plant Sci. 6: 1241, 2016.

Cho E.K., Hong C.B.: Over-expression of tobacco NtHSP70-1 contributes to drought-stress tolerance in plants. - Plant Cell Rep. 25: 349-358, 2006.

Dolatabadian A., Sanavy S.A.M.M., Gholamhoseini M. et al.: The role of calcium in improving photosynthesis and related physiological and biochemical attributes of spring wheat subjected to simulated acid rain. - Physiol. Mol. Biol. Plant. 19: 189-198, 2013.

Elgersma A., Soegaard K., Jensen S.K.: Interrelations between herbage yield, alpha-tocopherol, beta-carotene, lutein, protein, and fiber in non-leguminous forbs, forage legumes, and a grass- clover mixture as affected by harvest date. - J. Agr. Food Chem. 63: 406-414, 2015.

Farquhar G.D., Sharkey T.D.: Stomatal conductance and photosynthesis. - Annu. Rev. Plant Phys. 33: 317-345, 1982.

Gong M., Chen S.N., Song Y.Q. et al.: Effect of calcium and calmodulin on intrinsic heat tolerance in relation to antioxidant systems in maize seedlings. - Aust. J. Plant Physiol. 24: 371379, 1997.

Hochmal A.K., Schulze S., Trompelt K. et al.: Calciumdependent regulation of photosynthesis. - BBA-Bioenergetics 1847: 993-1003, 2015.

Hu Y.B., Sun G.Y., Wang X.C.: Induction characteristics and response of photosynthetic quantum conversion to changes in irradiance in mulberry plants. - J. Plant Physiol. 164: 959-968, 2007.

Huo Y.J., Wang M.P., Wei Y.Y. et al.: Overexpression of the maize psbA gene enhances drought tolerance through regulating antioxidant system, photosynthetic capability, and stress defense gene expression in tobacco. - Front Plant Sci. 6: 1223, 2016.

Ingram J., Bartels D.: The molecular basis of dehydration tolerance in plants. - Annu. Rev. Plant Phys. 47: 377-403, 1996.

Liu J., Shi D.C.: Photosynthesis, chlorophyll fluorescence, inorganic ion and organic acid accumulations of sunflower in responses to salt and salt-alkaline mixed stress. Photosynthetica 48: 127-134, 2010.

Lu C., Vonshak A.: Effects of salinity stress on photosystem II function in cyanobacterial Spirulina platensis cells. - Physiol. Plantarum 114: 405-413, 2002.

Reif C., Arrigoni E., Berger F. et al.: Lutein and beta-carotene content of green leafy Brassica species grown under different 
conditions. - Lebensm.-Wiss. Technol. 53: 378-381, 2013.

Rickauer M., Tanner W.: Effects of $\mathrm{Ca}^{2+}$ on amino-acid-transport and accumulation in roots of phaseolus-vulgaris. - Plant Physiol. 82: 41-46, 1986.

Tan C.S., Buttery B.R.: Response of stomatal conductance, transpiration, photosynthesis, and leaf water potential in peach seedlings to different watering regimes. - HortScience 107: 222-223, 1982.

Tan W., Meng Q.W., Brestic M. et al.: Photosynthesis is improved by exogenous calcium in heat-stressed tobacco plants. - J. Plant Physiol. 168: 2063-2071, 2011.

Verslues P.E., Agarwal M., Katiyar-Agarwal S. et al.: Methods and concepts in quantifying resistance to drought, salt and freezing, abiotic stresses that affect plant water status. - Plant J. 45: 523-539, 2006.

Wang W.B., Kim Y.H., Lee H.S. et al.: Analysis of antioxidant enzyme activity during germination of alfalfa under salt and drought stresses. - Plant Physiol. Bioch. 47: 570-577, 2009.

White P.J., Broadley M.R.: Calcium in plants. - Ann. Bot.London 92: 487-511, 2003.

Wise R.R., Ortiz-Lopez A., Ort D.R.: Spatial-distribution of photosynthesis during drought in field-grown and acclimated and nonacclimated growth chamber-grown cotton. - Plant
Physiol. 100: 26-32, 1992.

Xu C.B., Li X.M., Zhang L.H.: The effect of calcium chloride on growth, photosynthesis, and antioxidant responses of Zoysia japonica under drought conditions. - PLoS ONE 8: e68214, 2013.

Xu H.X., Heath M.C.: Role of calcium in signal transduction during the hypersensitive response caused by basidiosporederived infection of the cowpea rust fungus. - Plant Cell 10: 585-598, 1998.

Xu P.L., Guo Y.K., Bai J.G. et al.: Effects of long-term chilling on ultrastructure and antioxidant activity in leaves of two cucumber cultivars under low light. - Physiol. Plantarum 132: 467-478, 2008.

Xu Z.Z., Zhou G.S., Shimizu H.: Effects of soil drought with nocturnal warming on leaf stomatal traits and mesophyll cell ultrastructure of a perennial grass. - Crop Sci. 49: 1843-1851, 2009.

Zhou W.J., Lin X.Q.: Effects of waterlogging at different growth stages on physiological characteristics and seed yield of winter rape (Brassica napus L.). - Field Crop Res. 44: 103-110, 1995.

Zhu S., Zhou X.P., Wu X.M. et al.: Structure and function of the CBL-CIPK $\mathrm{Ca}^{2+}$-decoding system in plant calcium signaling. Plant Mol. Biol. Rep. 31: 1193-1202, 2013. 